\title{
Smart city research meets the geography of innovation The smart city programme of Enel in Rio de Janeiro and Santiago de Chile
}

\author{
L. Carvalho (a) \\ (a) Centro de Estudos em Geografia e Ordenamento do Território (CEGOT), Universidade do Porto, Icarvalho@letras.up.pt
}

\begin{abstract}
Over the last decade, a whole new assemblage of technologies, devices and innovations started to become deployed and experimented in cities under the banner of the "smart city" (e.g. sensors, software, city apps, open data platforms, urban operating systems, etc.). These developments mobilise different types of actors, ranging from global tech companies to local grassroots movements, drawing on multiple geographies, local and global, permanent and temporary. Scholarship in urban studies has developed a vigorous critique on smart city development but has paid less attention to the geographical, economical and (sociotechnical) innovation dimensions associated with it, which may influence how these innovations unfold and become embedded (or not) in society. By combining notions from economic geography and socio-technical studies of innovation, this paper explores how a "mobile" portfolio of smart grid/smart city technologies - developed by a global energy utility corporation - became anchored and recombined in different cities, and what do those processes depended upon.
\end{abstract}

Keywords: Geography of knowledge and innovation; smart city; anchoring; geography of sustainability transitions.

\section{INTRODUCTION}

Over the last decade, a whole new assemblage of technologies, devices and innovations started to become deployed and experimented in cities under the banner of the "smart city" (e.g. sensors, software, smart meters, smart grids, city apps, electric charging stations, etc.). These developments mobilise different types of actors, ranging from global tech companies to local grassroots movements, drawing on multiple geographies, local and global, permanent and temporary (Evans e al., 2016). Scholarship in urban studies has developed a vigorous critique on smart city development (e.g. Kitchin, 2016) but has paid less attention to the geographical, economical and (socio-technical) innovation dimensions associated with it, which may influence how these innovations unfold and become embedded (or not) in society.

By combining notions from economic geography and socio-technical studies of innovation, this paper explores how a "mobile" portfolio of smart grid/smart city technologies - developed by a global energy utility corporation - became anchored and recombined in different cities, and what do those processes depended upon. The research setting is the Global "Smart City Programme" of the Enel Group, the largest Italian electricity company. Since the early 2000 s, in order to cope with changing regulations, tariff prices and to enhance the efficiency in electricity distribution operations in Italy, Enel developed a pioneer investment in smart metering technologies and have been rolling out the technology across Italy; more recently, other technologies associated with smart grids, smart lightning, mobility, etc. were added to this portfolio, seeking to diversify the company's revenues beyond the regulated electricity market. As Enel expanded their operations to Latin America during the last decade (by buying local electricity companies), the group developed a global "Smart City Programme", with the ambition to rollout their Italian-developed technologies in other geographies. To that effect, Enel launched two pioneer smart-city "pilots" in Rio de Janeiro and Santiago de Chile.

The paper explores how the very same portfolio of technologies - championed within the corporate network of Enel - was anchored and recombined in place in rather different ways, ranging from deep modes of reciprocal learning (Rio de Janeiro) to more shallow knowledge contextualization (Santiago). In turn, the paper demonstrates how these different modes of knowledge anchoring - with include the technology, but also narratives and agendas, search heuristics, expectations, theories and values about smart city solutions - were influenced by 
a multi-scalar set of institutional contexts playing out in the two cities, influencing the extent to which knowledge about the smart city technology at stake was transformed and circulated again to new contexts.

The paper is organized as follows. Section 2 frames the conceptual starting points for this research. Section 3 details the research setting. Section 4 present the empirics and Section 5 concludes by highlighting a number of takeaways for research at the interface of smart city and the geography of innovation.

\section{CONCEPTUAL DEBATES}

A number of studies have been recently paying attention to the diffusion of smart city technology in society. One important issue relates to the notion of upscaling, or the extent and the process through which initial immature technologies gain traction and become diffused in places and social contexts different from the ones in which they were originally devised (van Winden and van den Buuse, 2017). Despite the often-positive narratives of policymakers and global technology corporations, these processes are fraught with difficulties. This is largely so because smart city propositions are infused with much more than technology - they involve many social aspects such as networks of actors, business models, expectations about their success, values, agendas, narratives, political and user assumptions, etc. For these reasons, apart from technologies and smart devices, smart city development requires social learning. Hence, a number of scholars started to conceptualize smart city development as a sociotechnical transition, requiring learning (about technology, but also about business models, new applications, perceptions, social and ecological impacts, values, etc.), social network formation (new advocates and wide networks of users and producers) and expectation building about the merits of new technologies and propositions, grounded on concrete initiatives and results (Carvalho et al., 2014; Carvalho, 2015; Sengers and Raven, 2015).

The development and the diffusion of smart meters, smart grids and energy-related innovations have been widely discussed in this literature, namely in a growing research stream focusing on sustainability transitions (Verbong et al., 2013). This research conceptualizes these technologies and innovations as "niches" vis-à-vis contemporary energy regimes, challenging mainstream (centralized, fossil fuel) energy production and distribution regimes. As technologies, markets, regulatory settings, infrastructure and user perceptions are still immature, their gradual diffusion to permeate (or even transform) energy regimes requires experimentation, namely in order to set in motion the aforementioned processes of learning, social network formation and expectation building (Schot and Geels, 2008).

Yet, energy regimes can hardly be challenged by single experiments in particular sites and locales (e.g. Kemp et al., 1998; Smith and Raven, 2012). For this reason, scholars in sustainability transitions speak about a "localglobal" model of diffusion, under which lessons from hands-on experimentation in concrete places - driven local networks of actors with their own interests and agendas - coalesce into a more influent "global niche" level composed by globally shared narratives, problem agendas, expectations, designs, search heuristics, strategies, etc. - that shape the development of the niche further, heightening its capacity to infuse change in dominant sociotechnical regimes (Geels and Deuten, 2006). In other words, knowledge and leanings from experimentation become increasingly "cosmopolitan", non-situated and mobile. As Schot and Geels (2008) put it,

"[niche] developments may start with one or a few projects, carried out by local networks of actors, who are interested in innovations for idiosyncratic or local reasons. The cognitive rules (...) that guide these projects are initially diffuse, broad and unstable. Local projects form test beds for these diffuse ideas (...). If learning processes in local projects are compared and aggregated, the cognitive rules at the more global niche level may gradually become more articulated, specific and stable" (p.543).

This conceptualization provides valuable insights into how the socio-cognitive orientation of the actors involved in socio-technical experimentation are locally formed, re-formed and globally retained, driving (or hampering) experimentation and the diffusion of innovations further. Yet, the local-global niche model has been criticized for saying little about where concretely new socio-cognitive frames become formed, through which channels they travel to become "global", and how they become re-embedded across places (Hansen and Coenen, 2015).

Recent studies have been addressing these geographical shortcomings, namely by highlighting notions of socio-spatial embedding and multi-scalarity (Coenen et al., 2012; Sengers and Raven, 2015). First, notions of sociospatial embedding contribute to understanding why certain experiments, niche activities and ultimately transition processes are more successful in some places than in others. This calls for an understanding of places not simply as 
"sites" where experiments unfold but as distinct assemblages of actors, networks and institutions with cultural, social and political texture, influencing the direction of experimentation and its ability to gain traction. Second, engaging with notions of multi-scalarity can contribute to highlighting the actors, processes and geographical scales through which experiments become intertwined and connect to one another towards the formation of broader alternatives to dominant socio-technical regimes. Overall, by bringing in explicit geographical notions, these studies suggest that sustainability transitions - such as the diffusion of smart city innovation in society evolve and grain traction through intrinsically spatial processes and, therefore, the concrete places where experiments form - and travel to - may largely influence their journeys and upscaling ambitions (positively or negatively).

These geographically informed views suggest that the diffusion and upscaling of smart city innovations involves spatial circuits through which learning, new networks and associated expectations are formed, transformed and (re-) assembled in concrete places before becoming mobile again (Carvalho and Lazzerini, 2008). Such a framework can be grounded on the notions of anchoring and mobility. The notion of anchoring has been used to understand change in territorial production and innovation systems under heightened mobility of production factors, notably knowledge (Crevoisier and Jeannerat, 2009; Vale and Carvalho, 2013). This work posits that under such a circulatory paradigm, the development of localized innovation systems became increasingly reliant on the capacity of a place to engage with resources and knowledge developed elsewhere, being that different localities will mobilise and integrate mobile knowledge in different ways (De Propris and Crevoisier, 2011). According with De Propris and Crevoisier (2011), anchoring is the process through which different places manage to "access, interact and capture knowledge, information, ideas or any form of tangible or intangible asset from other places (...)" (p. 173), relying on the (place-based) capacities of their actors, networks and institutional settings. Anchoring makes sense only in relation to its twin notion of mobility, that is, of movement of tangible and intangible assets across space. Under this perspective, knowledge is still produced and nurtured in concrete sociospatial contexts, and anchoring is the capacity of other places to re-contextualize/assimilate complex knowledge pieces and diffuse it locally, before it eventually becomes mobile again and flow to other contexts.

The concept of anchoring resembles the one of embeddedness. Yet, while embeddedness broadly refers to stable relationships between agents/actions and structures (e.g. social, institutional and cognitive environments) "belonging" to concrete places of origin, "anchoring embodies the idea that there exists an element of mobility between places, namely a tendency to open or a movement towards a new context" (De Propris and Crevoisier, 2011, p. 174), which implies a dynamic and frequent re-contextualization and transformation of knowledge and other mobile resources in the process. Notably, the capacity to re-contextualize mobile resources depend on the actors and relational assets in place, as well as on deliberate actions and policy efforts to strike the necessary alignments between localized assets and mobile resources (e.g. Coenen et. al, 2010; Vale and Carvalho, 2013). These abilities become increasingly pivotal for sustainability transitions and smart city-related experimentation, namely as a growing number of experiments and niche development processes are linked to trans-local and trans -national connections - namely through the deliberate actions of transnational companies to circulate their technologies and associated propositions (e.g. Carvalho, 2015; Hansen and Coenen, 2015, Wieczorek et al., 2015).

The aforementioned, geographically informed notions of anchoring and mobility have been recently applied in studies at the intersection of economic geography and sustainability transitions. For example, Binz et al. (2015) analysed how Beijing became a relevant node in on-site water re-cycling solutions through anchoring of external knowledge, namely by actively creating new local markets, mobilizing investment, fostering local spin-offs and locally legitimizing the solution (e.g. in local hotel segments). Yet, to put those processes in motion and circulate newly created knowledge, the role of foreign international organizations and global companies. In a similar vein, Carvalho et al. (2012) analysed how three cities (Curitiba, Hamburg and Goteborg) developed distinct assets that made them relevant international hubs for the creation, recombination, anchoring and diffusion of knowledge and ideas of sustainable mobility over time. Likewise, the fluid and rich mobility of new concepts and experiments to other places relied on the actions of globally connected yet also locally embedded actors, such as transnational corporations (carmakers and energy utilities) and well-connected mayors. Moreover, in a different vein, the study by Sengers and Raven (2015) showed that a concrete failure to adopt a rapid bus system in Bangkok became a burden to the actors aggregating knowledge on it, hampering the diffusion of the concept in other places.

\section{Summing up}

Smart city-related technologies and innovations are becoming increasingly mobile, namely as they are championed by transnational corporations with a global presence. Yet, the ways these propositions travel in space is far from frictionless. How they engage with particular locales and their socio-institutional configurations 
- or, in other words, how they become anchored - largely influence the ways through which new leanings, social networks, expectations and narratives about it form and transform.

\section{RESEARCH SETTING AND METHODOLOGY}

The remainder of this paper reports how these processes unfolded for the case of the Smart City Programme of Enel - the former, nationally owned Italian Energy Company. Over the last two decades, Enel developed a portfolio of smart, IT-infused energy devices to enhance distribution efficiency (e.g. avoid blackouts, manage energy demand, interact with users, remotely change and monitor energy plans and consumption) such as smart grid and smart metering solutions, as well as to cope with changing energy regimes, including electric charging stations for vehicles, smart lightning solutions, among others. In the early 2010s, Enel started a Smart City Programme in Italy and Spain in order to test the deployment of this portfolio of solutions in specific city districts, in an integrated fashion (e.g. in Genoa, Turin, Malaga and Barcelona). By doing so, the company envisioned to experiment how the assemblage of solutions would work together, involve users and assess their reactions to the new energy solutions, raise interest about their possibilities, develop new commercial opportunities beyond the regulated energy market, and, over time, change regulatory frameworks in favourable directions (e.g. to regulate or support the adoption of related technologies within the energy systems of different countries).

As Enel expanded overseas - namely buying energy production and distribution companies in Latin America - so did the company's smart city programme. In 2013, Enel launched two additional smart city pilots in Rio de Janeiro, Brazil (Municipality of Búzios) and Santiago de Chile, Chile. These pilots were designed in close articulation between the Enel "smart city group" in Rome - responsible for the distribution of smart city solutions worldwide and new Latin American electricity distribution subsidiaries (Distribution System Operators - DSO) in both cities: Ampla (Rio) and Chilectra (Santiago). The Enel smart city group transferred the technology within the corporation's boundary and provided local support to its implementation, while local DSOs would be tasked with the daily implementation of the pilots. To this effect, transnational corporate teams were formed, linking staff in the headquarters and subsidiaries (both through videoconferencing and intense moments of co-presence in Rome, Rio and Santiago), to deal with different sets of technologies and solutions being deployed in the pilots, leading, in general, to very similar organizational models governing the implementation of the pilots in the two cities.

This specific configuration - i.e. the same technologies and organizational models deployed in two subsidiary locations in Latin America - provided for a quasi-experimental research setting, fully controlling for technology, proponents and organization and allowing to observe the impacts of institutional variation in the two cities as explananda for different anchoring modes and processes of localized learning, social network formation and expectation building. In order to deep dive into these processes, and besides the analysis of several documents, reports, websites and other "grey" material, in-depth interviews were conducted in Rome (10), Rio (16) and Santiago (25) during 2013-2014, with global managers of Enel, staff involved in transnational knowledge mobility and several local actors in both cities, namely DSO's staff, experts, researchers, NGOs, local companies, policymakers, etc. Follow-up desk research was conducted during 2017 to assess the current status of the pilots and how knowledge developed in both contexts was transformed and reconfigured, and how it influenced the upscaling of Enel smart city programme.

\section{EMPIRICAL ANALYSES}

\subsection{Experimentation, anchoring and recombination results}

Although the experimentation objectives of Enel for both pilots were posited by their proponents in a very similar way - e.g. involving users, testing their reactions with new technologies, creating new business opportunities, changing regulatory settings - the way both experiments evolved in Rio and Santiago differ markedly, influencing knowledge anchoring and recombination modes and how they coalesced into the formation of delocalized niche learning, assumptions, narratives, search directions.

First, the specific socio-spatial in which both pilots evolved differed markedly, even if Enel Group's criteria was the same for both cases - namely to have local/national visibility; a proper scale to test technologies and monitor results; good energy infrastructure; diversity of users and consumption patterns; and easiness in mobilis- 
ing users to test new solutions. In the case of Rio, the pilot was developed in the Municipality of Búzios, a wellknown tourist city $180 \mathrm{Km}$ away from the city of Rio de Janeiro, catering from seasonal energy consumption, energy peaks, diversity of uses and visibility in a real city context. To this effect, a concrete deal had to be made with the Municipality to support experimentation, and to get local support (namely from municipal departments) for the pilot. In Santiago, the pilot was designed and implemented in a secluded business park (named "Ciudad Empresarial") and adjacent residential area in the periphery of Santiago. According with the pilot proponents, this would make the implementation of solutions more agile and speed up decisions - namely as they would depend essentially on private actors (the local DSO Chilectra and the park's managers) - while still providing for visibility and the experimentation of new technologies and business models with users and companies. The park's managers saw the deployment of these smart-city technologies as a way to enhance the profile of the location as "smart" and "green", and thus keep the park appealing to higher business segments.

The types of networks mobilized for experimentation were also very different across the two cases. In the case of Rio, a wide pallet of stakeholders became involved from the onset; beyond the DSO and the Municipality of Búzios, those included technology companies and manufacturers (e.g. to adapt smart meters to local standards; to develop other redundant wireless IT solutions for connectivity between meters and operative systems; to develop domotics solutions) and knowledge institutes (for the development of new electric vehicles and charging systems - e.g. an electric boat to link different beaches; and also apps and smart displays for remote energy metering linked with locally developed complementary technologies). Moreover, local citizens were involved to the full, namely through i) the widening of former community initiatives of Ampla (called "Consciência Ampla") to local citizens, e.g. training and hands-on mentoring and tips on how to consume energy more rationally; how to change behaviour and reduce consumption; how to balance family budgets; how to deal with smart metering; incentives to replace energy-inefficient home appliances, etc.; and ii) the development of a citizen network and several workshops to discuss energy-related smart city developments (by an independent knowledge institute), with an eye to discuss current developments, issues and "what was in it" for Búzios' citizens. In the case of Santiago, although efforts were made to explain door-to-door the impacts of smart meters on energy savings, the network of advocates was narrower - beyond the DSO and the park's management, it included essentially a number of technology retailers (e.g. sales subsidiaries of global corporations of domestic appliances, CCTV systems and electric buses), involved in showcasing their solutions (developed elsewhere) within the pilot.

These different setting and actor configurations led to different types of learning outcomes. In Rio, the pilot fulfilled its role testing the technologies in a new context, namely by collecting user's data and thinking about the implications of new smart energy solutions for current and prospective business models, as well as the necessary regulatory adjustments. Yet, the scope of experimentation also allowed for the development of new innovations, adaptations, as well as broader reflections about the technology's impacts in society and consumer behaviour (e.g. on the patterns of energy consumption and energy theft in Rio's cities); new modes of social engagement to discuss energy issues with the population; data and privacy agreements (e.g. between DSO and a widening networks of technology providers and knowledge institutes) and associated cooperative issues (and expected tensions) between DSOs and the local administration. In the case of Santiago, the concrete socio-spatial configuration of the pilot facilitated narrower types of learning, essentially focused on whether the technologies were applicable locally, whether users reacted positively, and on new business model development opportunities (e.g. the bundling of Enel's smart city portfolio with other provider's solutions, and the development of turnkey solutions including energy, domotics, water heating, solar panel connections and aftercare services).

In Rio, experimentation and associated social learning led, in general, to the development of favourable expectations about the technologies at stake. Hesitations and suspicions about its true impact and adoption potential remained among citizens, but the pilot managed to open up new horizons and show in practice the potential of the solutions in enhancing citizen's quality of life (e.g. energy savings, less blackouts, better street lightning, etc.) and led to joint discussions about smart city development based on hands-on, concrete experiments. Energy regulation agencies were closely involved and set up discussion groups to fine-tune the regulatory landscape in co-evolution with the piloting process. In Santiago, on the contrary, although regulators also paid attention to the pilot, their design and "habitat" (Ciudad Empresarial) was perceived by some stakeholders as elitist and too focused on local branding, focusing on a limited population cohort.

As a result, the initial Enel solution's portfolio - and their associated knowledge and "rules" (e.g. narratives, expectations, values) - became anchored rather differently in the two locales. In Rio, the mobile portfolio of technology and knowledge(s) was anchored and recombined in place, resulting in reciprocal learning between Italy and Rio before knowledge became mobile again and re-aggregated the "global niche" level. The pilot's design 
led to the "tropicalization" of the initial smart city solutions, with several actors contributing to deepen its fit to other conditions (e.g. new algorithms in the meter's software), but also to add new solutions and technologies to the bundle, developed locally (e.g. linked to water electric mobility, energy storage, new displays, etc.); moreover, new local practices on community engagement ("Consciência Ampla", smart citizen network) became discussed and promoted by Enel in other pilots around the world, notably in Europe. In the case of Santiago, the anchoring mode of the smart city portfolio resembled a pure re-contextualization pattern, in which local social dynamics did assimilate the new solutions in a concrete locale, but did not really transform it, apart from the consideration of new business models that could be tested around the set of pushed technologies, and eventually be tried out in other Latin American contexts. Table 1 synthetizes the analyses.

Table 1 - Experimentation results in Rio de Janeiro and Santiago de Chile. Source: Own elaboration.

\begin{tabular}{|c|c|c|}
\hline & Rio & Santiago \\
\hline $\begin{array}{l}\text { Spatial setting / } \\
\text { "habitat" }\end{array}$ & City-like environment (Búzios) & Business park (Ciudad Empresarial) \\
\hline Social Networks & $\begin{array}{c}\text { Heterogeneous and deep } \\
\text { (DSO, users, communities, manufacturers, SMEs, } \\
\text { R\&D institutes, local government) }\end{array}$ & $\begin{array}{c}\text { Homogeneous and loose } \\
\text { (DSO, tech retailers, users/ consumers); } \\
\text { NGOs, Universities and government at the fringe }\end{array}$ \\
\hline Learning & $\begin{array}{l}\text { Broad } \\
\text { (Tech-data-business models }+ \text { innovation policies, } \\
\text { user behaviour, social engagement, political issues) }\end{array}$ & $\begin{array}{c}\text { Narrow } \\
\text { (Tech-data-business models) }\end{array}$ \\
\hline Expectations & $\begin{array}{l}\text { (Broadly) shared by the actors, based on experi- } \\
\text { mentation, with regulatory feedback }\end{array}$ & Local branding, perceptions of elitism \\
\hline $\begin{array}{l}\text { Anchoring and } \\
\text { recombination }\end{array}$ & $\begin{array}{l}\text { Reciprocal learning (N-S-N) } \\
\text { "Tropicalization": New solutions in the bundle - EV } \\
\text { water mobility, storage, ITs. } \\
\text { New practices to foster community engagement } \\
\text { Positive expectations }\end{array}$ & $\begin{array}{l}\text { Contextualization }(\mathrm{N}-\mathrm{S}) \\
\text { Local tech push } \\
\text { Local business/selling models } \\
\text { Neutral-negative exp. }\end{array}$ \\
\hline
\end{tabular}

\subsection{Local contexts, institutional features and knowledge recombination possibilities}

As it became clear, similar ambitions and narratives around the role of smart city pilots - experiment, involve users, raise interest and change regulations - gave rise to rather different anchoring outcomes in place, thus influencing the ways through which the proposed smart city propositions unfolded, transformed and aggregated lessons as they became mobile again. One explanation for these differences and revealed recombination possibilities lie in the rather different local contexts and institutional features, playing out at different scales.

Experimentation and knowledge anchoring modes in both cities were influenced by higher-order, state-level institutional settings, related with political economy frameworks, regulatory settings and funding contexts. In the case of Rio, both the Federal and State Government had long tradition of deploying active industrial policies since the 1950s, with funding agencies largely supporting technological development and the development of new industries; by the time the Rio pilot was being devised, a new stream of this policy was focusing specifically on smart grids and associated innovations, and could thus shield and promote new technological developments around Enel's portfolio, supporting industrial and university's involvement in the pilot, in close articulation with the Federal electricity regulator (ANNEL). Moreover, DSO's investments in R\&D (e.g. for new appliances, apps, research programmes, etc.) and in community energy programmes (e.g. Consciência Ampla) were institutionally framed and promoted under a national regulation obliging energy companies to reinvest a percentage of their return-on-equity in $R \& D$ and social programmes, which in this case were easily attuned and transposed to feed the smart city pilot in Búzios.

None of these incentives and institutional settings was present in Santiago. On the contrary, the political institutional framing inherited from Pinochet's "Chicago boys" - an ultra-liberal group of economists that reorganized Chiliean's economic institutions in the aftermath of the 1973 cope d'état - limited the ability to nurture any sort of active industrial policy related with smart city and smart energy development. While such a framework largely facilitated the operations of large sales subsidiaries of foreign corporations in the country, it limited the established R\&D potential and advanced manufacturing base as witnessed it the case of Rio. Moreover, such an institutional framework was traditionally adverse to any sort of industrial protection, subsidies or tax 
rebates, which hampered the ability to provide incentives to the adoption of e.g. electric vehicles and other associated technology solutions, directing the experimentation to higher segments willing to pay higher prices for enhanced energy solutions - like the ones present at Ciudad Empresarial.

Moreover, local institutional contexts - such as local practices, social relations and planning routines - also played a significant role too shaping the experimentation directions and the potential for knowledge anchoring and recombination. In the case of Rio, previous social relations existed between Ampla and the Municipality of Búzios; the DSO had had in the past a negative experience with the deployment of another remote metering technology in deprived neighbourhoods (to prevent energy theft in the region), leading to severe societal backlash and political tensions as users felt the burden of paying for energy as formal electric consumption grew massively. Therefore, the development of community initiatives and related energy programmes with citizens became, since them, part of the company's "DNA", leading inclusively to the hiring of sociologists, planners and even local development experts to their staff. This tradition influenced the pilot by bringing citizen engagement programmes to the core of experimentation, namely to avoid similar societal and political backlash as in the past. In Santiago, local planning tradition gave strong leeway to the private initiative and it was thus perceived as normal when Enel's pilot was deployed in a private business condominium, protected from regular planning hurdles and bureaucracies. In this context, the focus on experimentation naturally turned into new business development, the showcasing of technologies and the experimentation of new revenue models associated with energy distribution, hence limiting knowledge recombination in place. Table 2 synthetizes these analyses.

Table 2 - Institutional features in both pilots. Source: Own elaboration.

\begin{tabular}{|c|c|c|}
\hline & Rio & Santiago \\
\hline $\begin{array}{l}\text { Higher order (State } \\
\text { level) institutions: } \\
\text { political economy, } \\
\text { regulatory and fund- } \\
\text { ing frameworks }\end{array}$ & $\begin{array}{l}\text { Active Industrial policy since } 1950 \text { s } \\
\text { ANNEL mandatory regulations for DSOs to invest } \\
\text { R\&D + social programmes } \\
\text { Smart grid industrial/innovation policy }\end{array}$ & $\begin{array}{c}\text { Pinochet's Chicago Boys Liberal Political Economy } \\
\text { Framework } \\
\text { Weak industrial/R\&D base } \\
\text { No room of manoeuvre for "protection", rebates or } \\
\text { subsidies }\end{array}$ \\
\hline $\begin{array}{l}\text { Local contexts: } \\
\text { practices, social } \\
\text { relations, planning } \\
\text { routines }\end{array}$ & $\begin{array}{c}\text { Relations between DSO-Municipality } \\
\text { Bad experience pushing tech; tradition of dealing } \\
\text { with electricity losses in deprived neighbour- } \\
\text { hoods ("Consciência Ampla" as "DNA") } \\
\text { àDSO focus on business + tech development + } \\
\text { engagement modes }\end{array}$ & $\begin{array}{c}\text { Relations between DSO-business park developer(s) } \\
\text { Private dominance/ Inequity tolerance in planning } \\
\text { à DSO focus on new revenue models and business } \\
\text { model innovation }\end{array}$ \\
\hline
\end{tabular}

\section{CONCLUSIONS}

Over the last decade-and-a-half, electric utilities invested in the "smartization" of their operations by developing smart grid-related technology: smart meters, grid automation, lightning systems, renewable-to-grid solutions, fast-chargers for vehicles, etc. By doing so, they envisioned enhancing operational efficiency, diversifying markets, business models and nudge change towards more sustainable modes of energy production and consumption. Moreover, as utilities progressively expand their operations overseas (e.g. through mergers $\&$ acquisitions), one ambition has been to diffuse those smart city technologies towards new geographies.

This paper explored the ways through which a corporate, supposedly "mobile" portfolio of smart-city/smartgrid technology becomes embedded and recombined in different locations, and what does this process depends upon. The research setting was the "Smart City Programme" of the Italian electric utility Enel and its smart-city pilots in South America: Rio de Janeiro and Santiago de Chile. Despite the relatively homogeneous organizational procedures and technologies deployed by Enel in the different locations, the ways the technology and its sustainability propositions became socially embedded and recombined in the two locations differed markedly, varying from rich "reciprocal learning" (Rio) to "allocation/assimilation" (Santiago).

By exploring these nuanced social-spatially dynamics, the paper provided insight into the geographies of smart-sustainability transitions, as well as into the roles (and limits) of transnational corporations nudging processes of global niche formation. As shown, while the pilot in Rio gave rise to new technologies, methods, strategies and expectations related with the upscaling of smart city technology in other parts of the world, the pilot in 
Santiago was essentially focuses on local assimilation of external knowledge, providing neutral to negative feedback to other projects. The analyses revealed many subtle yet very influential differences within "Latin American" institutional features, with impact on learning, the formation of advocacy networks and types of expectations formed in both pilots.

\section{REFERENCES}

BINZ, C., TRUFFER, B., \& COENEN, L. (2015). Path Creation as a Process of Resource Alignment and Anchoring: Industry Formation for On-Site Water Recycling in Beijing. Economic Geography, 1-29.

CARVALHO, L. \& LAZZERINI, I. (2018). Anchoring and mobility of local energy concepts: the case of Community Choice Aggregation, In Turnhein, B., Kivimaa, P. \& Berkhout, F. (Eds), Beyond Experiments: Understanding how climate innovations become embedded, Cambridge: Cambridge University Press.

CARVALHO, L. (2015). Smart cities from scratch? A socio-technical perspective. Cambridge Journal of Regions, Economy and Society, 8(1), 43-60.

CARVALHO, L., SANTOS, I. P., \& VAN WINDEN, W. (2014a). Knowledge spaces and places: from the perspective of a "bornglobal" start-up in the field of urban technology. Expert Systems with Applications, 41(12), 5647-5655.

CARVALHO, L., MINGARDO, G., \& VAN HAAREN, J. (2012). Green urban transport policies and cleantech innovations: evidence from Curitiba, Göteborg and Hamburg. European Planning Studies, 20(3), 375-396.

COENEN, L., BENNEWORTH, P., \& TRUFFER, B. (2012). Toward a spatial perspective on sustainability transitions. Research policy, 41(6), 968-979.

COENEN, L., RAVEN, R., \& VERBONG, G. (2010). Local niche experimentation in energy transitions: a theoretical and empirical exploration of proximity advantages and disadvantages. Technology in Society, 32(4), 295-302.

CREVOISIER, O., \& JEANNERAT, H. (2009). Territorial knowledge dynamics: from the proximity paradigm to multi-location milieus. European Planning Studies, 17(8), 1223-1241.

DE PROPRIS, L., \& CREVOISIER, O. (2011). From regional anchors to anchoring. In Cooke, P., Handbook of regional innovation and growth. Cheltenham: Edward Elgar.

EVANS, J., KARVONEN, A. \& RAVEN, R. (2016). The experimental city: new modes and prospects of urban transformation. London: Routledge.

GEELS, F., \& DEUTEN, J. (2006). Local and global dynamics in technological development: a socio-cognitive perspective on knowledge flows and lessons from reinforced concrete. Science and Public Policy, 33(4), 265-275.

HANSEN, T., \& COENEN, L. (2015). The geography of sustainability transitions: review, synthesis and reflections on an emergent research field. Environmental Innovation and Societal Transitions, 17, 92-109.

KEMP, R., SCHOT, J., \& HOOGMA, R. (1998). Regime shifts to sustainability through processes of niche formation: the approach of strategic niche management. Technology Analysis \& Strategic Management, 10(2), 175-198.

KITCHIN, R. (2016). Reframing, reimagining and remaking smart cities. Programmable City Working Paper 20, Maynooth University, Dublin.

SCHOT, J., \& GEELS, F. W. (2008). Strategic niche management and sustainable innovation journeys: theory, findings, research agenda, and policy. Technology Analysis \& Strategic Management, 20(5), 537-554.

SENGERS, F., \& RAVEN, R. (2015). Toward a spatial perspective on niche development: The case of Bus Rapid Transit. Environmental Innovation and Societal Transitions, 17, 166-182.

SMITH, A., \& RAVEN, R. (2012). What is protective space? Reconsidering niches in transitions to sustainability. Research policy, 41(6), 1025-1036.

VALE, M., \& CARVALHO, L. (2013). Knowledge networks and processes of anchoring in Portuguese biotechnology. Regional Studies, 47(7), 1018-1033.

VAN WINDEN, W., \& VAN DEN BUUSE, D. (2017). Smart city pilot projects: Exploring the dimensions and conditions of scaling up. Journal of Urban Technology, 24(4), 51-72.

VERBONG, G. P., BEEMSTERBOER, S., \& SENGERS, F. (2013). Smart grids or smart users? Involving users in developing a low carbon electricity economy. Energy Policy, 52, 117-125.

WIECZOREK, A. J., RAVEN, R., \& BERKHOUT, F. (2015). Transnational linkages in sustainability experiments: a typology and the case of solar photovoltaic energy in India. Environmental Innovation and Societal Transitions, 17, 149-165. 